\title{
FEMINISM AND HUMAN GENETIC ENGINEERING: A PHILOSOPHICAL CUM CATHOLIC PERSPECTIVE
}

\author{
George Uzoma Ukagba* \\ http://dx.doi.org/10.4314/og.v10i 1.8
}

\begin{abstract}
Human genetic in the area of Bio-ethics is a new, rapidly advancing Science. While genetic knowledge may be good per se, in itself, it can be put to good or bad use per secundi quid. In non-technical language, the author investigates Genetic Engineering within the context of its scientific orientation. Major areas of concern like feminist's view on genetic engineering, shall be treated and finally we shall apply catholic moral teachings in an attempt to penetrate the ontos-logos or Kpim of the various genetic interventions.
\end{abstract}

\section{Introduction}

Human genetic engineering, a recent one in medical science and practice, is one done for the general improvement of the human species. It works on the genetic constitution of the human species and combines the various elements of knowledge obtained through genetic engineering to reconstruct the life of the human person.

Negatively, it tries to remove unhealthy genes, to repair damaged ones, to perfect ones that are weak and to ensure better general performance of the human person through the genes ${ }^{1}$. There is much excitement at the possibilities offered by the knowledge of genes we are acquiring, although there are also fears that this knowledge will not be well-used.

Genetic knowledge is good in itself, like other kinds of scientific knowledge. The practical uses to which it is put, and for which it is acquired, can be either good or bad. Unfortunately, the current situation is that we can diagnose many more conditions than we know how to cure. Diagnosis can lead to serious even lethalforms of discrimination, especially where an unborn child is found 
to have an abnormal gene or where women are raped and ipso-facto infected with HIV condition.

This article therefore deals with women's response to genetic engineering and a critique of this response in the light of catholic moral theory and the principle of non-contradiction.

\section{Background Science}

In historical parlance, the body of us started as a single cell, when we were first conceived. Presently, we are made up of billions of cells, which come in very different kinds. Some are blood cells, some are brain cells, and some are bone marrow cells. Watt observes that: "most of our cells contain the same information, which is found in the genes; however this information is used in different ways in different cells",2.

A gene is a piece of information or 'recipe' for making a protein. Genes are made of a chemical called DNA. DNA is stored in packages called 'chromosomes', on which the genes are located. Chromosomes come in 23 pairs, and one of each pair is inherited from each of our parents. Unlike other cells, sperm and ova (eggs) have, at some stages, one of each chromosome rather than a pair of each kind. When the sperm and ovum come together at conception, a new human being is created who has 46 chromosomes: two of each kind. This new human being is the zygote, or one-cell embryo.

As the embryo grows in the body of its mother, its cells are constantly dividing. At first these cells are not committed to forming one part of the body rather than another. Cells can even separate off from the rest of the embryo to form a new embryo: a twin brother or sister .However, as time goes on the embryonic cells become more and more specialized into the different types of cell which the older human being needs. Some genes are switched on and others switched off, depending on what is needed by the part of the body affected. Genes work as part of the cell, and cells work as part of the body as a whole, to keep it functioning as it should. 


\section{Disorders in Genetic Constitution}

It has been proven that the features of our parents may be passed to us through the genes we inherit from them. Both positive and negative (weakness) features are inheritable. For instance, our organs of sight or hearing or taste may be bad, or we may be prone to develop diabetes Miletus or heart disease in later life, as our parents have done.

For many conditions there is both a genetic component (which may involve a number of genes) and a strong environmental component. Certain diseases which run in the family' can be developed if we have a certain kind of life style (modus Vivendi). For example, if diabetes runs in our family, as it presently does, we may be much more likely to develop it ourselves if we consume lots of fizzy drinks, starchy food and very ripped fruits or concentrated sugar.

Many conditions are caused by a number of genes interacting with the environment. However, some conditions, such as cystic fibrosis, are caused by only one defective gene. Watt is the view that,

Cystic fibrosis involves a mutation in the gene responsible for forming a protein whose absence causes chest infections, and eventual damage to the lungs. Cystic fibrosis is a recessive condition, which means that to be affected we need to inherent copies of the faulty gene from both our parents ${ }^{3}$.

Our parents may not themselves be affected, but may be carriers, so that some of their children are affected. Other diseases such as Huntington`s are dominant, which means that we would be affected even if we had only one copy of the faulty gene, inherited from one of our parents.

\section{Circumventing Genetic Disorders}

Modern medicine has suggested various ways of preventing genetic disorders like cystic fibrosis, diabetics, Parkinson, sickle cell or other acquired illness like HIV and cancer etc. Among the various 
suggestions is not having a child if one finds that one is a carrier. In principle, this could be a worth-while option, depending on how we go about it. We could, for instance, take into account our carrier status in deciding who (or if) to marry. Or a couple who are already married could choose to avoid conception through natural family planning, so that they do not have intercourse at times when the women are fertile. Whether a couple have reason to avoid conceiving a child who has a high chance of having some genetic condition will depend, for instance, on whether they are able to meet the child's needs.

However, what geneticists often mean by 'preventing' conditions such as cystic fibrosis is screening for the condition in the womb, and aborting any baby found to be affected. There are very serious moral reasons against this as we shall discuss later. Someone with cystic fibrosis has as much right to live as anyone else. Instead of taking the life of a child because he or she has some medical problem, we should do our best to help the child to have as good a life as he or she can.

\section{Possible Cure}

Is it possible to treat those with cystic fibrosis? There are some treatments currently available, but non which bring about total cure. A person born with such genetic disorders can expect to live no more than three or four decades, unless better treatments can be found. Recently, a new way of dealing with these disorders and other inherited conditions, has been discovered i.e.; by giving the patient a normal copy of the defective gene.

Gene therapy is a way of treating disease by delivering genes to affected cells. Scientists are working on the possibility of replacing an abnormal with a normal gene at the very same site on the chromosome. It may be possible also to build an artificial human chromosome with the normal gene already on it .This could be a way of avoiding the disruption of the work of existing DNA, it could also enable large amounts of new DNA to be delivered to the cell. So far, however, gene therapy has focussed on adding the gene to the 
DNA on existing chromosomes, in the hope that where it attaches, it will do good and not harm.

Two major type of gene therapy have been discovered as possible ways of treating genetic disorders: Germ-line and Somatic gene therapy. Germ-line gene therapy is generally directed towards affecting in one way or another future generation, and not just an individual patient. On the occasion of its pragmatic realization, its positive or negative effects would be inherited by subsequent generations.

Germ-line therapy would probably be carried out in connection with in vitro fertilization (IVF) [creating a 'test-tube baby' in the laboratory].This would itself raise serious moral problems, as we shall be discussing later in this work. It is obvious that many scientists and doctors agree that germ-line therapy is too dangerous to consider at the present time.

"Somatic gene therapy", on the other hand, according to Watt ...involves a genetic alteration which is aimed at affecting only an individual patient...there might, in some cases, be a risk of affecting the germ-line cells, and hence the patient's descendent, however, this would not be the intention " ${ }^{4}$. Somatic therapy can be carried out on children, including unborn children. Despite its drawback, encouraging results have been seen in some areas, for example, in helping blood vessels to grow in the legs of patients who would other-wise have needed amputations (e.g. diabetic patients).

In future, somatic therapy may become a standard form of treatment both for inherited diseases and acquired diseases such as cancer and AIDS. It is even possible that genetic intervention could be extended towards the enhancement of normal human features e.g. height, beauty or intelligence. Apart from the treatment of genetic disorders, genetic engineering has led to other experimentation like cloning and stem-cell researches, artificial insemination.

Cloning is the reproduction of the same examples of the embryo such that one copy has exactly same biological constitution like the others. This portends to bring in a revolution in medical 
sciences as one could replace not only parts, but even whole organisms and entire beings with their clones ${ }^{5}$.

In Vitro Fertilization by which eggs from one woman are fertilized by sperms from any man in an artificial womb in the laboratory. Sperm and ovum banks now exist to ensure constant supplies. This is contrasted to In Utero Fertilization, the fertilization of the embryo through the natural copulation process.

ARTIFICIAL INSEMINATION: In this process, the fertilised foetus is transferred to any woman: the original owner of the egg if at her demand, to a woman for her choice of agreement. The latter case is surrogate motherhood in which the surrogate or borrowed mother carries and delivers the baby for the legal mother. Recall the 1968 case of the surrogate mother Mary Bett Whitehead of New Jersey who refused to relinquish her biological daughter, and thereby sparked up a landmark count case in the United States. Transfer and/or freezing of Embryos now permit people to decide on which type of baby, when and how to have such babies and meanwhile allow technicians to experiment.

STEM CELLS research is the rediscovery of the root cells that constitute the human body or the bodies of other organism. Stem Cells are versatile cells in the body which are both able to renew themselves and to produce more specialized cells. They can therefore be used to repair damaged human organs or tissue and perhaps, in the future, to grow up organs outside the body. There are, however, possible dangers of stem cell use in transplantation. These dangers include causing cancer, and rejection of 'foreign` stem cells by the body of the patient.

\section{Feminism, Discrimination and Human Genetic Engineering}

Female sexuality in its entire ramification has been subjected to particular scientific and moral scrutiny throughout modernity. It has also constituted a central concern in feminist struggles. While the first women's movement that emerged in the last decades of the $19^{\text {th }}$ century prioritized the fight for civic and political equality for women, sexuality and right over their bodies nevertheless constitute an important area for the critique of existing gender relation ${ }^{6}$. 
Feminists are divided over these latest advances in genetic cum reproductive technology. Like every novel thing, it is still shrouded in secrecy. One obvious fact however fact however is that feminists presently are engage with issues bordering on justice, on fair treatment and right not only to be seen but equally to be heard. These rights include amongst others, reproductive right. Demand for their reproductive right is part of the general demand for justice ${ }^{7}$.

It is pertinent to observe that women are victims of various discriminations: rape, unwanted pregnancies, poverty, venereal diseases and some genetic disorders. Over and above this, they are equally socially and psychologically discriminated on non-fertility ground, since most of the above happen in and around their bodies, most feminists have come to the conclusion that solutions to their problem must lie in their hands and should therefore not allow any patriarchal interest to have control over their bodies.

New techniques of In Vitro fertilization are an extension of women's choice to have babies where order-wise it would have been difficult. Again, this is often useful to women who became infertile because of infection from an IUD contraceptive. In cases of rape leading to pregnancies where the foetuses are diagnosed for some genetic disorders, gene therapy intervention could be used to abort such foetus and more women under this category are gradually embracing this new age phenomenon. It is equally obvious that Artificial Insemination offers a welcome chance for women to conceive independently of a relationship with a man.

In the case of cloning for birth, some feminists have endorsed this so that those women who carry certain genetic disorders can have unaffected children, those who are totally infertile-women with no ova- to have a child to whom they are genetically related.

It has been suggested by Watt (2001:16) that some feminists might want to produce a child by cloning in order to 'replace' a dead child with a clone who would be her identical twin. Others want to produce a clone of someone who had some desired features such as high intelligence, or musical ability. Others again might want to 
clone themselves- perhaps thinking that they would 'live on` after death in their clone ${ }^{8}$.

\section{The Morality of Genetic Engineering in the Light of Catholic Thought}

It is the considered view of Iroegbu that: "the general objective of gene research is the acquisition of more and specialised knowledge about the genetic constitution of the human body". He insists... that this knowledge ought to enable us arrive at more precise information that would be useful in the (re)construction of life, treatment of disease, and maintenance of health ${ }^{9}$. Gene research studies man in view of doing good to man and his existential universe.

Like all innovation, genetic engineering stuff is fraught with difficulties, complications, dangers and risks. The task before us all scientist, ethicist and consumer lay person, is to understand the issues at stake, weigh the risks ascertain that we are not being plunged into a waterloo of medical genetic abyss or extravaganza. While we must let science advance, that advancement must be veridique, proper and sustainable. Science at all levels must be at the service, not enslavement of humanity. As the present president of United States B. Obama stressed on yahoo news of $10^{\text {th }}$ of March 2009 during the opening up of stem cell work-science inquires:' Our government has forced what $\mathrm{i}$ believe is a false choice between sound science and moral values". He went on to approve federal funding for stem cell research. This action of the new president will, in effect, allow scientists to create their own guidelines without proper moral restraint.

Opponents saw it however, differently, a defeat for morality in the most basic question of life and death. Opinions on this issue differ.

What is the position of the Catholic thought in this regard and in the light of non-contradiction philosophically speaking? The Catholic thought as presented by various church men in different encyclicals and documents, is not opposed, in principle, to trying to promote genetic health. Whether this is right or wrong, in specific 
cases, will depend on how we go about. Pius X111 calls attention to the fact by insisting that,

It is not wrong, in principle, to tell those who carry genetic disorders the risk of passing on those disorders to any future child. However, it would be wrong to deprive those who carry genetic disorders of their right to get married and start a family ${ }^{10}$

It would be even more wrong to encourage couples to screen their children before they are born, and abort any child who has a certain disorder $^{11}$. The disabled have the same right to live as anyone else; they should be lovingly welcomed and supported by their families, and the rest of society.

\section{Respecting the Human Embryo}

The Catholic Church teaches that all human beings, of whatever age, should be respected as 'persons' i.e., as being with full human dignity and rights. Even if we may not be sure if the very early embryo is a person, we should behave as if it were ${ }^{12}$.

In practice, many church documents assume that the embryo is a person from conception. Certainly, the embryo, in catholic teaching, should always be treated as a person: a human being with a human soul. Philosophically, a human person is not just the soul, and not just the body, but is both physical and spiritual. The soul is the form of the body or life principle -i.e.; it makes the body alive. Because the human person is not just the soul, but it is also the body, we harm the person if we harm his or her living body. To quote a papal statement on genetics: "...in the body and through the body, one touches the person itself, in its concrete reality"13.

Obviously, this being the case, some genetic interventions can be ruled out at once. To produce a clone embryo so as to destroy it and use its cells in transplantation would be very wrong indeed. It would tantamount to treating the embryo as an object: as a means to an end. The same would apply to any intervention where the embryo was, or might be, deliberately destroyed- for example, germ-line 
therapy where the plan was to throw away those embryos for which the treatment failed. It would certainly apply to experiments where the embryo was subjected to lethal interventions: i.e.; where it $\mathrm{w}$ never intended to allow the embryo to survive.

John Paul II insists,

...to use an embryo as a pure object of analysis or experimentation Is to attack the dignity of the person and the human race. Indeed, No one has the right to determine the threshold of humanity for an individual being, which would amount to claiming for himself an inordinate power over his fellow $\operatorname{man}^{14}$.

He further stated:

...therefore at no moment in its development can the embryos be the subject of tests that are not beneficial, or of experimentation that would inevitably lead to its destruction or mutilation or irreversibly damage it, for man`s nature itself would be .mocked and wounded. The genetic inheritance is a treasure that belongs or could belong to a unique being who has the right to life and integral human growth $^{15}$.

If scientists or even our parents had eliminated us while we were still embryos, what would have become of us today, this time of socalled medical expertise? This is conscience searching interrogation.

It is pertinent to observe that there is a scientific argument to this ethical duty to respect embryos. The genetic study of the human DNA ascertains that at conception, the Deoxyribonucleic acid (DNA) is the same for each human person. This implies that what its genetic code at conception age (1 hour) is exactly what is at day 14 , at year 10, at year 55, indeed throughout the person`s life.

The developmental factors are nothing but developmentbuilding on what his DNA was already. To eliminate any embryo as some feminists argue is to eliminate a human being. Some scientists debate on the exact origin of human life. When does life begin 
remains an ongoing debate for some. Is it at hour one, day one, day 14 or some even settle for only at birth? Anything not yet born and kept in the lapse of the mother is not yet a human being.

It is very important to observe her that it is not the number of days one stays in this world that makes a person, person. According to Iroegbu:

It is the reality of conceived at all, of having the composition of the DNA of personhood and above all of being granted body and soul by God the creator and fashioner of all lives, including laboratory- lives. At the point of conception (natural or artificial), God always grants each composition the animating soul. It is this power that makes the being become human like others, a rational animal, an embodied soul and a living human being. And once the soul is given, the being is fully human. It is the imago Dei (image of God). It deserves fullest reverence $^{16}$.

\section{Heterogeneous IVF is Problematic}

The church opposes IVF even without such further interventions as selecting or manipulating sperm or ova or embryos so as to have 'designer babies'. Are there rational grounds for this opposition? Some Catholic scholars have attempted some answers. When a child is sexually conceived in marriage, by parents who are open to life,(i.e.; not using contraception) the child comes into being in a way which is suited to express the parents 'unreserved self-giving'. The couple can in this way give themselves, and accept each other, unconditionally, without "keeping back" their fertility or their permanent commitment.

Whether or not their action does result or can result-in a new human being (they will not always be fertile) it is the kind of act which is worthy of resulting in a new human being. It is God who creates the human soul, however, the married couple lay themselves 
open to doing what may culminate, in the right conditions, in God`s act of creation. The couple are prepared, by giving themselves in a way which is open to a further gift of life, to see the child as a gift they receive, not a product they produce.

In contrast, IVF embryos are not received by the couple as an outcome of sexual self-giving. Rather, IVF embryos are produced, like manufactured objects, not by an interpersonal act but by the manipulation of materials.

The case of using sex cells from various persons and combining them to produce human embryos raises problems that can complicate life more than one thinks at the beginning. For instance to get a donor man or woman to offer or sell her sex cell to fertilize that of the partner in marriage has yielded to court cases that are intractable. If the generosity of the donor is altruistic, one could argue that the help rendered to the couple who has now a child is more than the tensions.

This is why Janet D McDowell argues that "conceptions through IVF ought to not simply be tolerated; they should be celebrated, for they enable otherwise infertile couples to join in passing along the gift of life"17. Iroegbu observes that the above assertion is an optimist viewpoint worth respect. However, it does not remove the difficulties associated with the complications of new birth technologies.

Embryo transfer, ova and embryo banking, now being done in countries like Australia, though these help in making genetically connected families, they run significant risks of confusing lineage, distorting traditional family structures, and/ or depersonalising human reproduction ${ }^{18}$.

\section{The Church on Cloning and Stem Cell Research}

The teaching of the Catholic Church with reference to cloning and stem cell research is unambiguous. While being pastorally conscious of its mission of healing and helping people and groups in needs, the church goes on to warn about abuses and possible manipulation by science of our very parts, our persons and our human values and intimate family relationships. The church is not an enemy of 
research. Yet as Iroegbu observes: "the church is not a blind promoter of research; research must be true, objective and formative, not deformative. Indeed she has the position that sees research as for man and not man for research" $"$.

On this note the outspoken Archbishop of the diocese of Cologne in Germany, Joachim Cardinal Meisner has said, in the overall tradition of ecclesiastical teaching on medical research and practice, that though a forerunner in speaking against risks and abuses, the church has nevertheless been in strong defence of positive research. By positive research is to be understood, in the words of the Cardinal, the research 'that is devoted to and has its limits in the dignity of the human person'.

In respect to the research on stem cells, only that type of research on stem cells is to be ethically justified, which does not kill or lead to the killing of human embryos or the human foetus. They are not moral those researches that are done for purely research or non-therapeutic purposes, just to use the human parts and discard them at will after the research. Such an approach makes man a means rather than an end, an object rather than subject. We should not make some persons mere means to others ${ }^{20}$.

Cloning, on the other hand, if it ever became a safe and feasible procedure, would have much in common with IVF, as a form of manufacturing children involving their quality control. However, there are features of cloning which make it even worse preparation for accepting the child who would result. Apart from the features it shares with IVF, cloning also raises other problems concerning the deliberate production of a child who is a genetic copy- though not a perfect copy- of some existing person.

Children need a sense of separateness both from their parents and from others. They need to feel free to live their own lives. The fusion of the parent's genetic contributions to form a new and distinct individual presents itself as at once a symbol of relatedness, and at the same time one of difference. The child is genetically related to both parents, but is still genetically unique, just as his or her life is both a new start and owes a debt to the past. The 
visible difference of the child from the parent-and normally, from his or her siblings- reminds all concerned that he or she is a separate human being with a separate life to lead.

Parenthood involves- or should involve- acceptance of the child as a new human person. However, parents are all too often tempted to try to control the child in inappropriate ways, and to withhold their love or acceptance if the child is not the kind of child they want. Cloning will do nothing to help parents guard against this particular temptation, as cloning is itself a very strong form of parental control.

Closely connected with cloning is genetic enhancement. In principle, the church is not opposed to enhancement intervention per se. Enhancement may be positive or negative. Positively, parents are generally concerned to make their children 'better' in a range of different ways which are not 'mechanical', but involve the child using his or child natural abilities. For example, they give the child violin lessons, or tutoring in maths. Negatively, parents do sometimes intervene 'mechanically' on their children, intending to confer on them some non-medical benefit.

Watt is of the view that the wish for mechanical nonmedical enhancement-for oneself or one's children may express a moral vice such as vanity, greed or self-absorption.(Cheating at sports through drug enhancement). It may divert people away from projects where they give each other mutual help into more solitary, depersonalised forms of self-improvements. A child may be teased by her classmates because she is somewhat slow, or somewhat unattractive: here the priority should be to change the attitude of the classmates, not the child herself ${ }^{21}$.

Consequently, enhancement whether Germ-line genetic or somatic therapy, may involve a failure of respect for the person enhanced, it may also involved a misuse of time, money and attention which should have been spent on other worthwhile ventures. Above all, both Germ-line therapy and somatic therapy raise some moral problems concerning genetic relationships. Earlier in this work, we looked at the suggestion that feminists with mitochondrial disease could have IVF using only the nucleus from 
their own ovum, which would be placed in the ovum of another woman prior to fertilization. Such a fragmentation of motherhood would be morally wrong, quite apart from the issue of the nonsexual production of the child. The church insists that we should not deliberately create a child with more than one candidate for the role of mother, nor should women help conceive children they do not intend to bring up.

Feminists' reproductive right does not confer on women the audacity to be reckless in the reproduction or non-reproduction of babies. Children need to feel secure in their identity, and accepted by their parents. 'Rival' parents who take no part in their upbringing will do nothing to provide them with this sense of security.

\section{Conclusion}

The Catholic Church investigates man as a psycho-somatic being, a being so to say who exist both materially and immaterially. It would amount to a metaphysical extravaganza to cognize man spiritually, but equally, it is essentially wrong to conceive man materially. The spiritual aspect of man, in the context of existence, cannot be comprehended without reference to the body and vice versa. Sometimes the body or the soul may be diseased and this can trigger some negative effects on each other.

Materially, genetic disorders are bad in themselves and through man's power of auto-transcendence, he seeks always and everywhere to eliminate the various illness that keep him down from realising his great potentials. However, illness is not the ultimate evil, and good can come from illness both for the person affected and for the rest of society. There is nothing degrading in being dependent on others, as many people inevitably are, on the contrary, this can build community of people between human beings.

While the Catholic Church, in particular, has always been involved in curing the sick, she has also been involved in supporting those who cannot be cured. The church has also emphasized what many sick and disabled people themselves believe, that much good can come from accepting our bodily limitations. 
Christians and other men of good will should be careful to ensure that in trying to treat some condition, we continue to value those human beings who have that condition. Most often than not, the affected individual, in clinical genetics, is treated as something to be literally discarded if he or she cannot be cured. It is pertinent to note, that all human beings must be respected, whether they are adults or children, including children in the womb or very young human embryos.

Feminism in all its ramifications should be able to come to terms with the moral imperatives that are universal and timeless. Despite the fact that they ve been victims of various kinds of discrimination, exploitation oppression, they should not, in reverse discrimination, turn a destructive tendency towards the infant, the unborn, the infirm. They should, in the spirit of motherhood, take up these greatest challenges of our time and promote a culture of life of everybody.

Sickness, sufferings may come our way from time to time, but perhaps it is through some major of suffering that we can overcome the cross, it is through losing ourselves for the sake of something greater that we can gain it back.

We shall therefore conclude with this clarion call from Iroegbu, the author of the "Kpim Series" in Philosophy,

This is a clarion call to respect lives, all lives, including the life of the human embryo. Life may never be wilfully destroyed in the name of research. Life is life, and all life is equal. This is fundamental ethical Imperative. It is the bottom line of all our study, research and preoccupation with science, art, with medicine ${ }^{21}$.

*George Uzoma Ukagba PhD is a Senior Lecturer in the Department of Philosophy and Religions, University of Benin, Benin City. 


\section{References}

1. P. Iroegbu, "Medical Practice: Experimentation with Human Subjects, transplants, Placebo" in Kpim of Morality: Ethics: General, Special and Professional (eds) by P.Iroegbu and A.Echekwube.[Ibadan: Heinemann Educational Books, 2005] p.570

2. H.Watt, Gene Therapy And Human Genetic Engineering. [London: Catholic Truth Society and the Linacre Centre, 2001] p.5

3. Ibid; p.7

4. Ibid; p.11.

5. P.Iroegbu, "Ethics of Science and Technology" in Kpim of Morality: Ethics: General, Special and Professional, (eds) by P.Iroegbu and A.Echekwube. [Ibadan: Heinemann Educational Books, 2005] p.350.

6. See Religious Tolerances. Org Human Reproductive and Therapeutic Cloning, http://www.religioustolerance.org/cloning.htp,p.2.

7. S.A.Watkins, M.Rueda, M.Rodriguez, Introducing Feminism, [Cambridge: Icon Books Ltd, 1999] p.161.

8. Watt, op.cit; p.16.

9. P.Iroegbu, “Gene Therapy and Gene Mapping: Ethical Undercurrents" in Kpim of Morality op.cit; p.614.

10. Pope Pius x111, Address to Primum Symposium Geneticae Medicae, Sept. 7, 1953, p.3

11. John Paul 11, Evangelium Vitae paragraph 63.

12. Ibid; p.60.

13. John Paul 11, The Ethics of Genetic Manipulation, Address to the World Medical Association, Oct.29.1983.

14. John Paul 11, Society must protect embryos, (Address to a working party on the legal and clinical aspects of the Human Genome Project, November 20, 1993).

15. Ibid; 
16. P.Iroegbu, ' 'IVF Invitro Fertilization, Embryology, Making Babies", in Kpim of Morality op.cit; p.606.

17. Janet D.Mc Dowell, The future of Genetic Research, http:www//htm, p.6.

18. J.D.Mc Dowell, "Ethical Implications of In Vitro Fertilization" in S.E.Lammers and A.Verhey (eds), On Moral Medicine, [MICHIGAN: w.b.Eerdmans Pub. Co. $1998]$ p.507.

19. P.Iroegbu, "Stem Cell Technology and Ethics", in Kpim of Morality, op.cit; p.632.

20. J.Meisner, "Limits of Progress" in foundation for life magazine, Sept. 2002, p.4.

21. See P.Iroegbu, “'Stem Cells: Technology and Ethics”,p.633, See also the work of Father Pacholcczyk himself. http://www.frc,org. The Catholic Teaching on this and related issues can be read among others in the following official documents: Documents of Vatican Council Two: Gaudium et Spes, 14f; Pope Paul vi Mater et Magistra; Humanae Vitae; Pope John IlFamiliaris consortio; congregation of Doctrine of faith: Donum vitae( signed Josef Cardinal Ratzinger Rome, 1987). 